\title{
FRICTION WELDING OF CERAMICS TO METALS
}

\author{
D. Bonte ${ }^{1}$, B. Derynck ${ }^{1}$, P. De Baets ${ }^{1}$, W. De Waele ${ }^{1}$ and K. Faes ${ }^{2}$ \\ ${ }^{1}$ Ghent University, Laboratory Soete, Belgium \\ ${ }^{2}$ Belgian Welding Institute, Belgium
}

\begin{abstract}
This paper discusses the progress in a master thesis about friction welding of ceramics to metals. An existing friction welding machine has to be adapted for the experimental part of this research. The required capabilities of this machine are discussed in this paper. As an introduction, a general explanation about friction welding is given. The results of a literature survey on friction welding of ceramics to metals are discussed. The aim of this survey was to determine the process parameters required to obtain a good weld quality. It became clear that few literature exists on friction welding of these materials and that the cited values for the process parameters vary widely. Based hereon, a range of process parameter values was used to make certain design choices. Because a laboratory machine is aimed at, it has to be able to function at varying settings of the process parameters, including testing at higher rotational speeds. Finally, process windows illustrating sound combinations of friction pressure and specimen diameter are calculated. The design choices entail certain restrictions on the capabilities of the machine. These restrictions define the boundaries of the process windows.
\end{abstract}

Keywords friction welding, ceramics, metals, machine design

\section{INTRODUCTION}

The final goal of this research is joining ceramics to metals using the rotational friction welding process. Rotational friction welding is a forge welding process in which the necessary heat is generated as a result of the friction forces between two surfaces. These surfaces are rotated against each other under axial pressure. When sufficient heat is generated, the rotating part is stopped and a forge pressure is applied. In figure 1 the main parameters of the friction welding process are displayed as a function of time.

Friction welding is a process that can be easily automated. It can be used to join different materials that cannot be welded with conventional welding processes. Furthermore, friction welding also results in a smaller heat affected zone because of the smaller heat input.

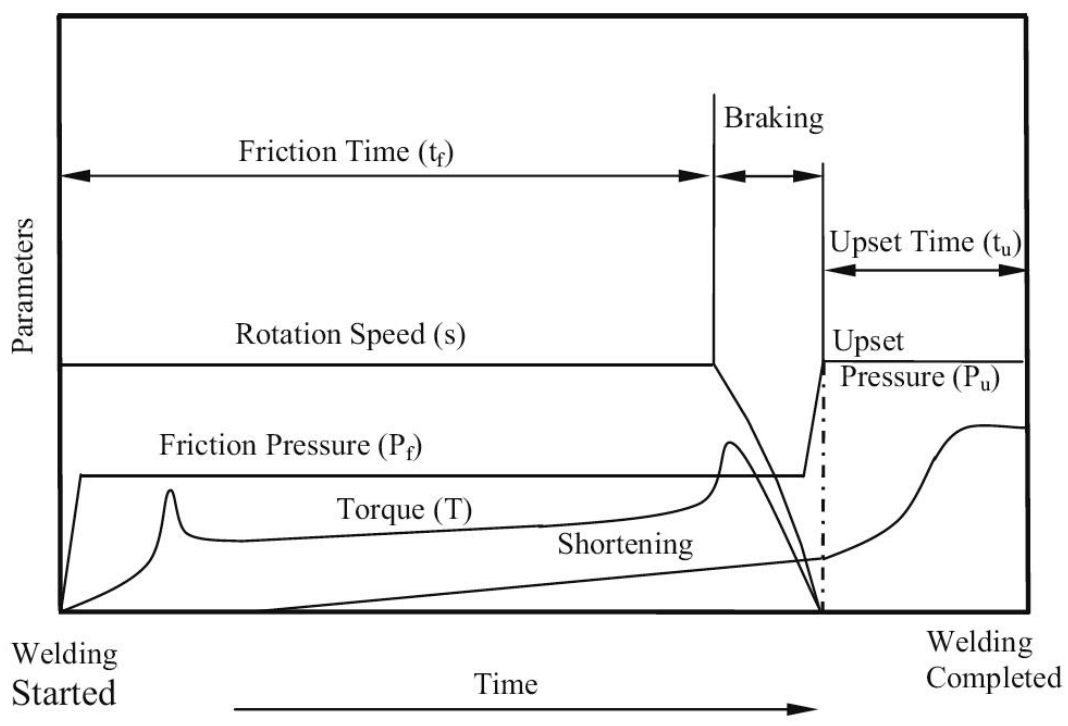

Figure 1: Friction welding process [1]

For this research, an existing friction welding machine has to be redesigned to meet the required settings of the process parameters. This work includes making some important design choices and developing process windows. 


\section{PROCESS PARAMETERS}

\subsection{Literature on friction welding parameters}

In the last decades, quite a lot research effort has been made to tackle the different parameters that determine a good weld. However, this research mainly focused on the 'conventional' steel-steel shaft or tube connections. The rotational speed, the axial force during the friction and forging phases and the duration of the friction and forging periods are the major values that affect the behaviour during the weld cycle and the resulting weld quality. The speed is mostly represented by the circumferential speed at the outer diameter of the cylindrical specimen. During a short literature survey, it was soon found that research on welding of ceramics to steel or copper by friction welding is very restricted. Based on the information from about twenty references [2-27], the following observations can be made:

1. Friction welding of ceramics to metals has not yet been addressed frequently.

2. The experiments that were conducted, were mainly performed with laboratory-scale samples $(10-30$ $\mathrm{mm}$ diameter).

3. A frequently used ceramic material is $\mathrm{Al}_{2} \mathrm{O}_{3}$ (can be considered the exemplary material to experiment with), sometimes with the use of an aluminium interface layer to facilitate the bonding process.

4. Circumferential speeds vary between 0,5 and $2,5 \mathrm{~m} / \mathrm{s}$, with a peak value of $7,55 \mathrm{~m} / \mathrm{s}$ (for joining $\mathrm{Al}_{2} \mathrm{O}_{3}$ to aluminium).

5. The friction duration varies from 1 to 10 seconds, the forging duration is typically a bit longer.

6. Friction and forging (axial) pressures vary in a wide range. They are usually determinative to get an allowable weld quality for a specific situation.

The following general conclusions can be formulated:

1. With materials like $\mathrm{Cu}$ and $\mathrm{Al}$, higher rotational speeds are required than with steel specimens [2]. This can be explained by the higher heat conduction in $\mathrm{Cu}$ and $\mathrm{Al}$ in comparison with steels. The temperature increase needed to achieve a weld, requires a faster heat input (same amount of energy in shorter time) to compensate the heat sink by conduction. Since the machine has to be as versatile as possible, this will be taken into account during the design.

2. Since friction and forging forces vary in the examined literature, it will be required to vary them and to investigate their relationship with the friction torque. These values need to be measured during the weld cycle.

\section{$2.2 \quad$ The machine constraints}

The Belgian Welding Institute acquired a friction welding machine in the late 1960's (Thompson Friction Welder 40 ton). The 40 ton refers to the axial force of $400 \mathrm{kN}$ that can be delivered by the main cylinder. The machine was able to produce friction welds at 4 different speeds, between 500 and $2000 \mathrm{rpm}$. The friction welder had a $30 \mathrm{~kW}$ motor and was capable of welding rods up to $50 \mathrm{~mm}$ diameter and tubes up to $80 \mathrm{~mm}$.

The machine has been adapted several times in order to make other test situations possible. The last upgrade was in 2000-2001, when a $160 \mathrm{~kW}$ electric motor with a frequency inverter was installed, to make medium-scale tube friction welds possible. In this configuration the machine was able to weld tubes up to 5" (outer diameter 141 $\mathrm{mm})$ at a speed of max. $300 \mathrm{rpm}$.

\subsection{The friction welder in 2009-2010}

In the machine upgrade for this master thesis, the achievable speed is a determining issue. A circumferential speed up to $8 \mathrm{~m} / \mathrm{s}$ has to be achieved to get more insight in the influence of rotational speed on weld quality, especially in the case of welding copper or aluminium. After some calculations and comparisons, it was concluded that the rotational speed should be maximum $4000 \mathrm{rpm}$. This is an important requirement, making the use of some of the original components impossible. Furthermore, the $160 \mathrm{~kW}$ motor is to be used, because of the variable speeds that can be delivered by the frequency inverter. The axial hydraulic cylinder will be a minor issue; the original one is practically sufficient for all welding conditions. Further design considerations are explained later.

\section{DESIGN CHOICES}

To meet the process parameters discussed above, the existing friction welding machine has to be adjusted. In particular the combination of a high rotational speed, a high force and a low price is a challenging combination.

This entailed multiple design choices and several alternatives for the different functions were examined, see table 1. 


\begin{tabular}{|c|c|c|c|c|c|}
\hline Power Transmission & Timing belt & V-belt & Chain & Gearbox & Push belt \\
\hline Speed Control & $\begin{array}{l}\text { Frequency } \\
\text { control }\end{array}$ & $\begin{array}{l}\text { Continuously } \\
\text { Variable } \\
\text { Transmission }\end{array}$ & & & \\
\hline Clamping & $\begin{array}{c}\text { Hydraulic } \\
\text { power chuck }\end{array}$ & Manual chuck & Clamping Bush & & \\
\hline Bearings & $\begin{array}{c}\text { Tapered roller } \\
\text { bearing }\end{array}$ & $\begin{array}{l}\text { Spherical roller } \\
\text { thrust bearing }\end{array}$ & $\begin{array}{l}\text { Hydrodynamic } \\
\text { bearing }\end{array}$ & Plain bearing & Hybrid bearing \\
\hline Belt Tensioning & Gravity & $\begin{array}{l}\text { Sideways tilting } \\
\text { of motor }\end{array}$ & Slide rail & Tension idler & Lifting the motor \\
\hline Torque Measuring & Torque sensor & Load cell & & & \\
\hline
\end{tabular}

Table 1: Design Choices

For the power transmission a timing belt was chosen. Strong advantages exist in comparison to the other alternatives. A timing belt is able to transmit the required torque and is more affordable than a gearbox. Chains have a lot of resonating frequencies leading to vibrations and noise, especially combined with a variable speed. A timing belt is also a slip free transmission which assures an accurate speed measurement.

For the speed control, the frequency inverter is used because this component was already available on the existing machine.

For the clamping, a manual chuck was chosen. The price is much lower than for a hydraulic chuck, and it has a lot more flexibility in possible clamping diameters than a clamping bush.

The bearings must be able to rotate at both low and high speeds (400 to $4000 \mathrm{rpm}$ ) and sustain a heavy axial load $(400 \mathrm{kN})$. A combination of a spherical roller thrust bearing and a spherical roller bearing is chosen. Spherical roller thrust bearings can sustain a very high axial load, combined with a radial load. The spherical roller bearing will be mounted such that it is able to slide in the direction of the axial load. As a result it does not need to resist any of the friction and forging force, only the light pretension load.

For the tensioning of the timing belt, an idler wheel is selected. This induces additional bending of the belt but is the easiest way of tensioning, knowing that the electrical motor weighs too much to be used for tensioning.

For the torque measurement, a torque sensor is added, again because of design simplicity. A load cell would require a lever at the non-rotating side. Also the non-rotating clamping unit should then be able to rotate.

A more detailed overview of the advantages and drawbacks of each alternative can be found in appendix 1 . By means of illustration, a 3D-view of the future machine is presented in figure 2.

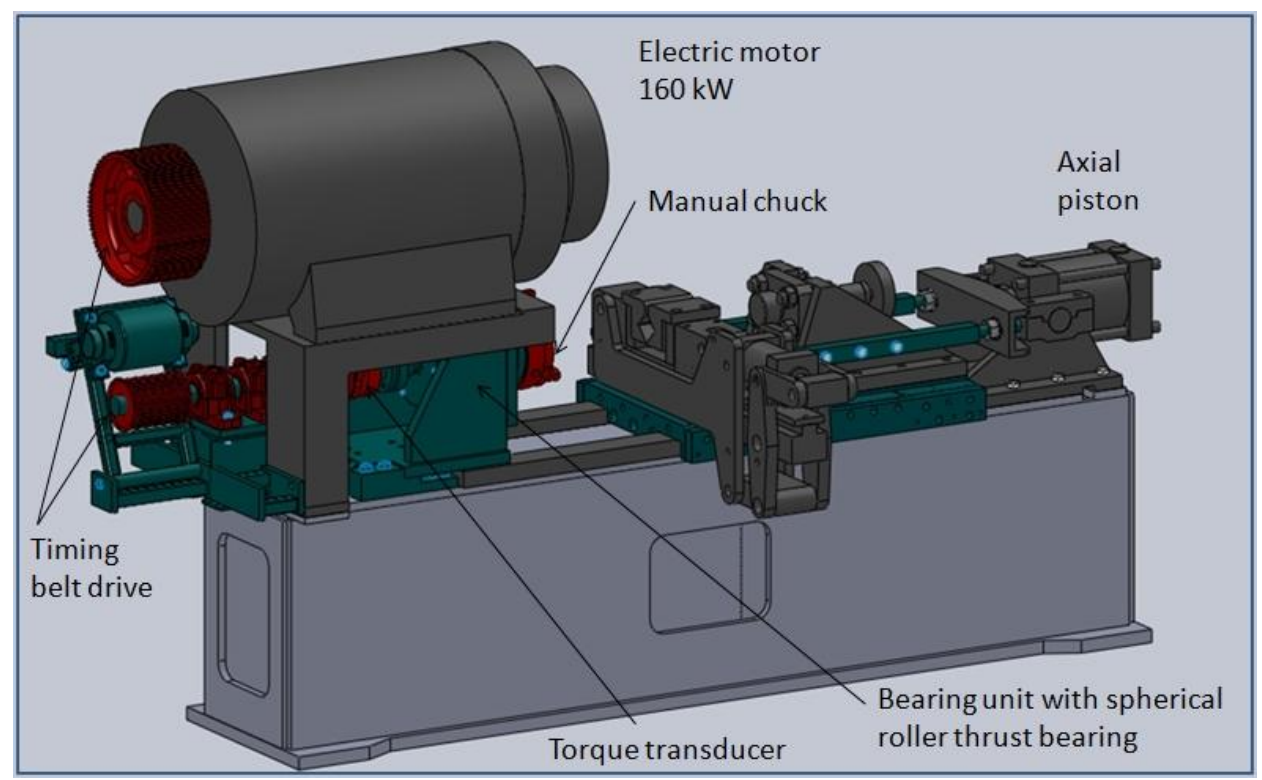

Figure 2: 3D view of the future adjustments of the friction welder 


\section{PROCESS WINDOW}

As described above, machine components were selected to achieve a range of possible parameter settings. Also an overview of the machine capabilities was given. In an attempt to visualize these capabilities, a process window is constructed (see figures 3 and 4). By choosing a specimen geometry (rod or tube) and dimension (diameter), one can read from the graphs in what range the initial friction pressure can be varied.

In figure 3 the process window for a rod is shown. The green shaded area displays the allowable welding conditions for creating a weld. The sound area is bounded by 6 curves. The purpose of each one is described below.

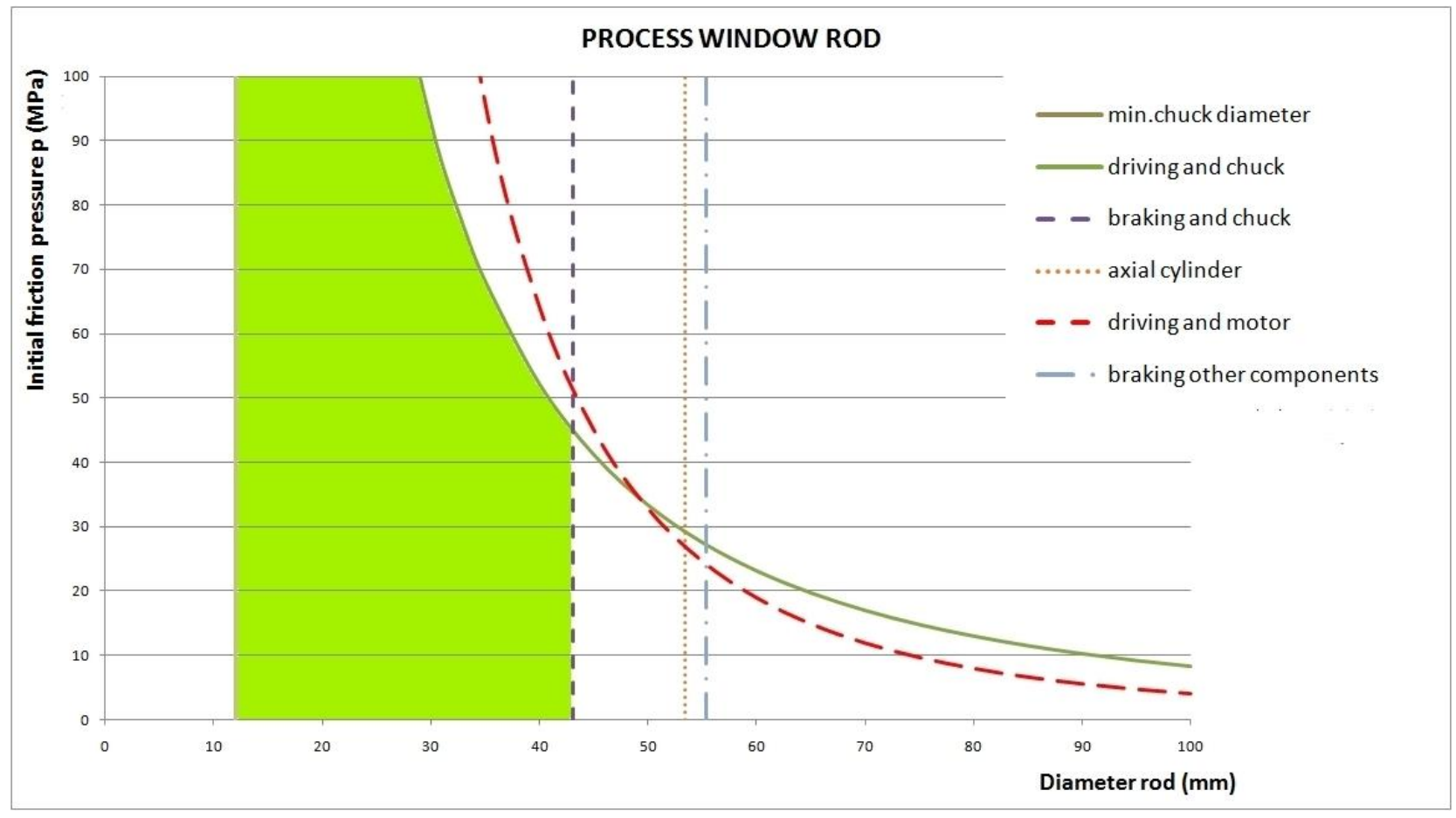

Figure 3: Process window for a rod

1. Minimum chuck diameter - vertical solid line

The minimum component diameter to clamp in the selected chuck is $12 \mathrm{~mm}$.

2. Driving and chuck - hyperbolic solid line

It has to be prevented that the specimen slips in the chuck jaws during the friction phase. This condition can be expressed by a simple friction torque equation, and be solved as $p \sim 1 / R^{2}$ :

$$
M_{\text {chuck }}=F_{\text {chuck }} \mu_{\text {chuck }} R=M_{\text {friction weld }}=\frac{2 \pi}{3} \mu_{\text {ini }} p R^{3}
$$

3. Braking and chuck - vertical dashed line

Also while braking, the specimen is not allowed to slip in the chuck jaws. The same formula (1) applies, but now the contact pressure $p$ is assumed to be $100 \mathrm{MPa}$. A specific value for the maximum outer radius is obtained, independent of the initial friction pressure.

4. Axial cylinder - vertical dotted line

The maximum axial force produced by the hydraulic cylinder limits the maximum contact surface (and according diameter of the rod) that can be friction welded (A maximum friction pressure of $100 \mathrm{MPa}$ is assumed to be reached in every weld at the end of the friction period).

$$
p=\frac{F_{\text {cylinder }}}{A} \Rightarrow A_{\max }=\frac{F_{\text {cylinder }}}{100 \mathrm{MPa}} \Rightarrow R_{\max }
$$

5. Driving and motor - hyperbolic dashed line

The electric motor can deliver a maximum torque of $1076 \mathrm{Nm}$ to the weld (calculated after speed increase). This value is compared to the friction torque, and gives a relationship $p \sim 1 / R^{\wedge} 3$ :

$$
M_{\text {motor } \text {, } \max }=1076 \mathrm{Nm}=M_{\text {friction weld }}=\frac{2 \pi}{3} \mu_{\text {ini }} p R^{3}
$$


6. Deceleration of other components - vertical dash-dot line

Deceleration can be a dangerous situation for some other components as well. Normally, the motor is braking the weld. But the solidifying weld can cause a huge torque, which is able to exceed the motor braking torque. In that case the weld is braking the motor! If the weld braking torque would be excessive (when it exceeds $2000 \mathrm{Nm}$ ), other components like the belt and the torque transducer could be damaged. To prevent problems, either the diameter of the weld specimen has to be limited, or a safety device must be incorporated.

Similar curves can be calculated for tubular specimens. In figure 4 a process window for a tube is presented; here we assumed the tubes to have a wall thickness proportional to their outer radius.

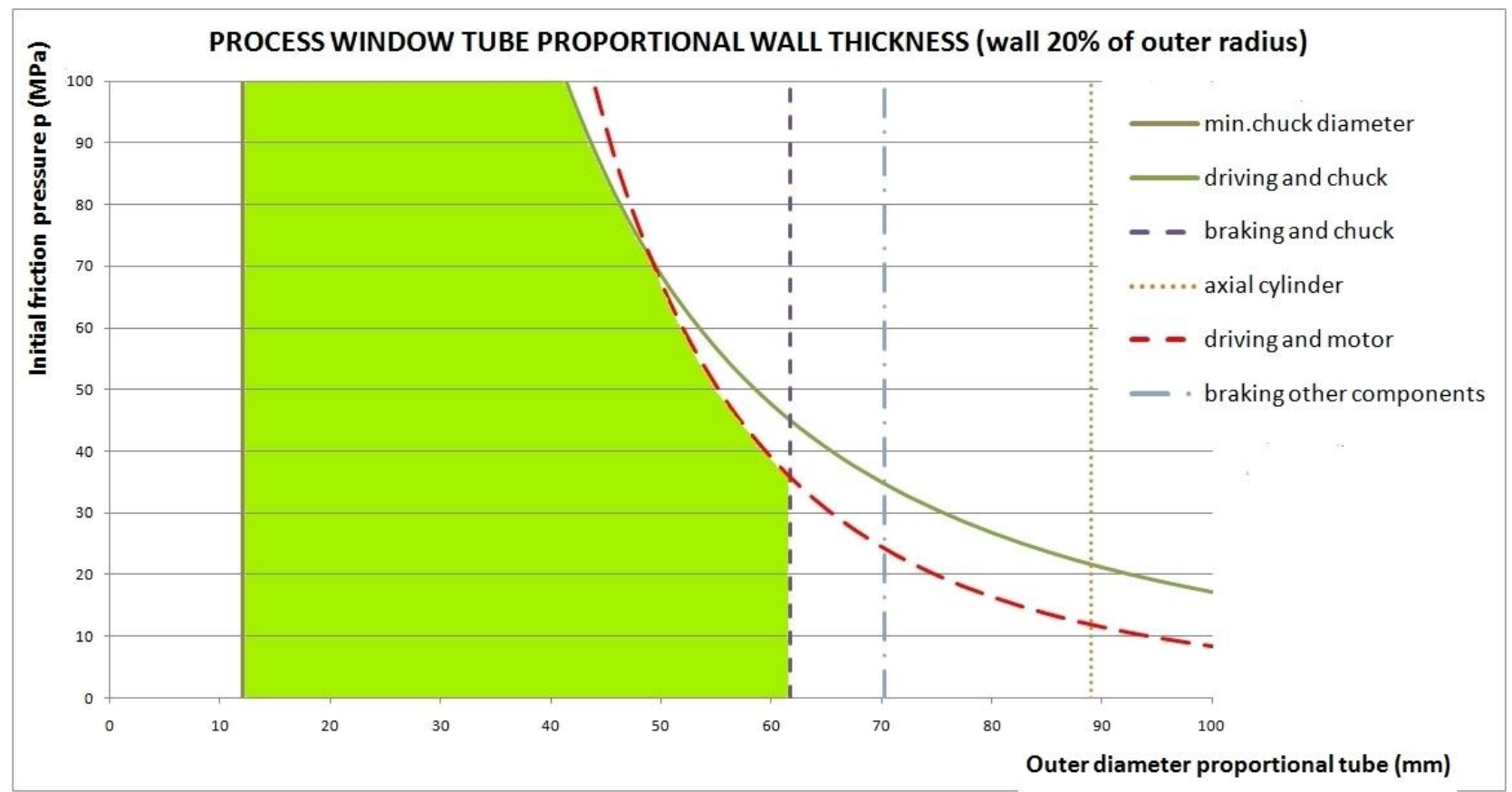

Figure 4: Process window for a tube (wall thickness proportional to outer radius)

\section{CONCLUSIONS}

This paper presents the progress of a master thesis about friction welding of ceramics to metals. Since an existing friction welding machine has to be redesigned and rebuild, the determination of the necessary capabilities of the future machine is an issue addressed in this paper.

A literature survey was conducted to find the determining process parameters and to obtain common ranges of values for them. Few literature on the subject of friction welding of ceramics to metals was found and the reported parameter settings showed a lot of variability.

Secondly, this range of process parameter settings was used to make certain design choices. Since a laboratory machine is aimed at, it has to be able to operate at both low and high speeds, with varying torques and axial loads. This leads to the design solution with a spherical roller thrust bearing, a timing belt drive and a torque transducer as the main new machine components.

Finally, process windows showing allowable combinations of friction pressure and specimen diameter were calculated. The design choices entail certain restrictions on the testing possibilities of the machine, which are represented by the boundaries of these process windows. These graphical representations allow to verify at a glimpse if a specimen can be welded.

\section{NOMENCLATURE}

$\begin{array}{llllll}M & \text { torque } & \mathrm{Nm} & F & \text { force } & \mathrm{N} \\ p & \text { pressure } & \mathrm{Pa} & R & \text { radius } & \mathrm{m} \\ \mathrm{A} & \text { surface } & \mathrm{m}^{2} & \mu & \text { Coefficient of friction } & -\end{array}$

\section{ACKNOWLEDGEMENTS}

The authors would like to acknowledge the support of the Belgian Welding Institute and Labo Soete of the Ghent University, The input of R. Desmet and W. Ost on minor and major design issues is highly appreciated. 


\section{REFERENCES}

[1] M. Sahin, Joining of stainless-steel and aluminium materials by friction welding The International Journal of Advanced Manufacturing Technology, 41 (5-6), 487-497, 2009.

[2] B. Humphreys, A practical guide to friction welding, Thompson Friction Welding Ltd., 1998.

[3] Ates, H., Turker, M., \& Kurt, A.. Effect of friction pressure on the properties of friction welded MA956 iron-based superalloy. Materials and Design, 28 , pp. 948-953, 2007.

[4] Brogle, E., Staubli, M., Nazmy, M. Y., \& Gausmann, D. Patent: Friction welding of y-titanium-aluminide to steel body with nickel alloy connecting piece there between, 2006.

[5] Duffin, F., \& Bahrani, A. Friction welding of mild steel: the effects of varying the value of deceleration. Metal Construction and British Welding Journal, pp. 125-132, 1973.

[6] Duffin, F., \& Bahrani, A. The deceleration phase in friction welding of mild steel. Welding Research International, 6 (1), pp. 1-19, 1976.

[7] Fauzi, M. A., Uday, M., Zuhailawati, H., \& Ismail, A. Microstructure and mechanical properties of alumina- 6061 aluminium alloy joined by friction welding. Materials and design, Accepted manuscript, 2009.

[8] Hascalik, A., \& Orhan, N. Effect of particle size on the friction welding of Al2O3 reinforced 6160 Al alloy composite and SAE 1020 steel. Materials and Design 28, pp. 313-317, 2007.

[9] Inkson, B., \& Threadgill, P. Friction welding of FeAl4O Grade 3 ODS alloy. Materials Science and Engineering A258, pp. 313-318, 1998.

[10] Kanayama, K., Tasaki, Y., Machida, M., Kume, S., \& Aoki, S. Joining of ceramics by friction welding. Transactions of the Japan Welding Society, 16 (1), 95-96, 1985.

[11] Keat, Y. C., Jamaludin, S. B., \& Ahmad, Z. A. The effect of varying process parameters on the microhardness and microstructure of Cu-steel and Al-Al203 friction joints. Jurnal Teknologi, University Teknologi Malaysia 41(A), pp. 85-95, 2004.

[12] Kobayashi, A., Machida, M., Matsuda, T., \& Nishiwaki, N. Study on the initial torque characteristics of friction welding. IIW Database, Doc. No. III-1150-00, pp. 1-9, 2000.

[13] Li, Z., Maldonado, C., North, T., \& Altshuller, B. Mechanical and metallurgical properties of MMC friction welds. Welding Research supplement, pp. 367s-373s, 1997.

[14] Lin, C., Mu, C., Wu, W., \& Hung, C. The effect of joint design and volume fraction on friction welding properties of A360/SiC (p) composites. Welding Research supplement, pp. 100s-108s, 1999.

[15] Lindemann, Z., Skalski, K., Wlosinski, W., \& Zimmerman, J. Thermo-mechanical phenomena in the process of friction welding of corundum ceramics and aluminium. Bulletin of the Polish Academy of Sciences; Technical Sciences 54-1, pp. 1-8, 2006.

[16] Midling, O., \& Grong, O. Continuous drive friction welding of SiC-particulate reinforced aluminum composites. International Trends in Welding, Science and Technology, ASM International, (pp. 1147\{1151), 1993.

[17] Mohamad, Z. N., Luay, B. H., \& Zainal, A. A. Alumina-mild steel friction welded at lower rotational speed. Journal of materials processing technology 204, 279-283, 2008.

[18] Nakamura, K., \& Nakahara, S. Study on friction welding - Torque in frictional process and optimum welding conditions for plain carbon steels. The Government Mechanical Laboratory of Japan, pp. 1-18, > 1965.

[19] Ochi, H., Yamamoto, Y., Kawai, G., \& Suga, Y. Tensile strength of friction welded joints of copper alloys to steels. Proceedings of the Eighteenth (2008) International Offshore and Polar Engineering Conference, Vancouver (Canada), pp. 272-276, 2008.

[20] Ozdemir, N., Sarsilmaz, F., \& Hascalik, A. Effect of rotational speed on the interface properties of friction-welded AISI 304L to 4340 steel. Materials and Design 28, pp. 301-307, 2007.

[21] Shin, H.-S., Jeong, Y.-Y., Choi, H.-Y., Kato, H., \& Inoue, A. Joining of Zr-based bulk metallic glasses using the friction welding method. Journal of Alloys and Compounds 434-435, pp. 102-105, 2007.

[22] Sketchley, P. D., Threadgill, P., \& Wright, I. Rotary friction welding of an Fe ${ }_{3} A l$ based ODS alloy, 2000. URL: http://www.twi.co.uk/j32k/protected/band 8/sppdsjuly2000.html

[23] Sketchley, P. D., Threadgill, P., \& Wright, I. Rotary friction welding of an $\mathrm{Fe}_{3} \mathrm{Al}$ based ODS alloy. Materials Science and Engineering, A329-331, pp. 756-762, 2002.

[24] Voiculescu, I. The behaviour of aluminium matrix composites in welding processes, > 1997.

[25] Weiss, R. Residual stresses and strength of friction welded ceramic/metal joints. Welding research supplement, pp. 115s-122s, 1998.

[26] Yilbas, B. S., Sahin, A. Z., Kahraman, N., \& Al-Garni, A. Z. Friction welding of St-Al and Al-Cu materials. Journal of Materials Processing Technology 49 , pp. 431-443, 1995.

[27] Zimmerman, J., Wlosinski, W., \& Lindemann, Z. R. Thermo-mechanical and diffusion modelling in the process of ceramic-metal friction welding. Journal of Materials Processing Technology 209, pp. 16441653, 2009. 


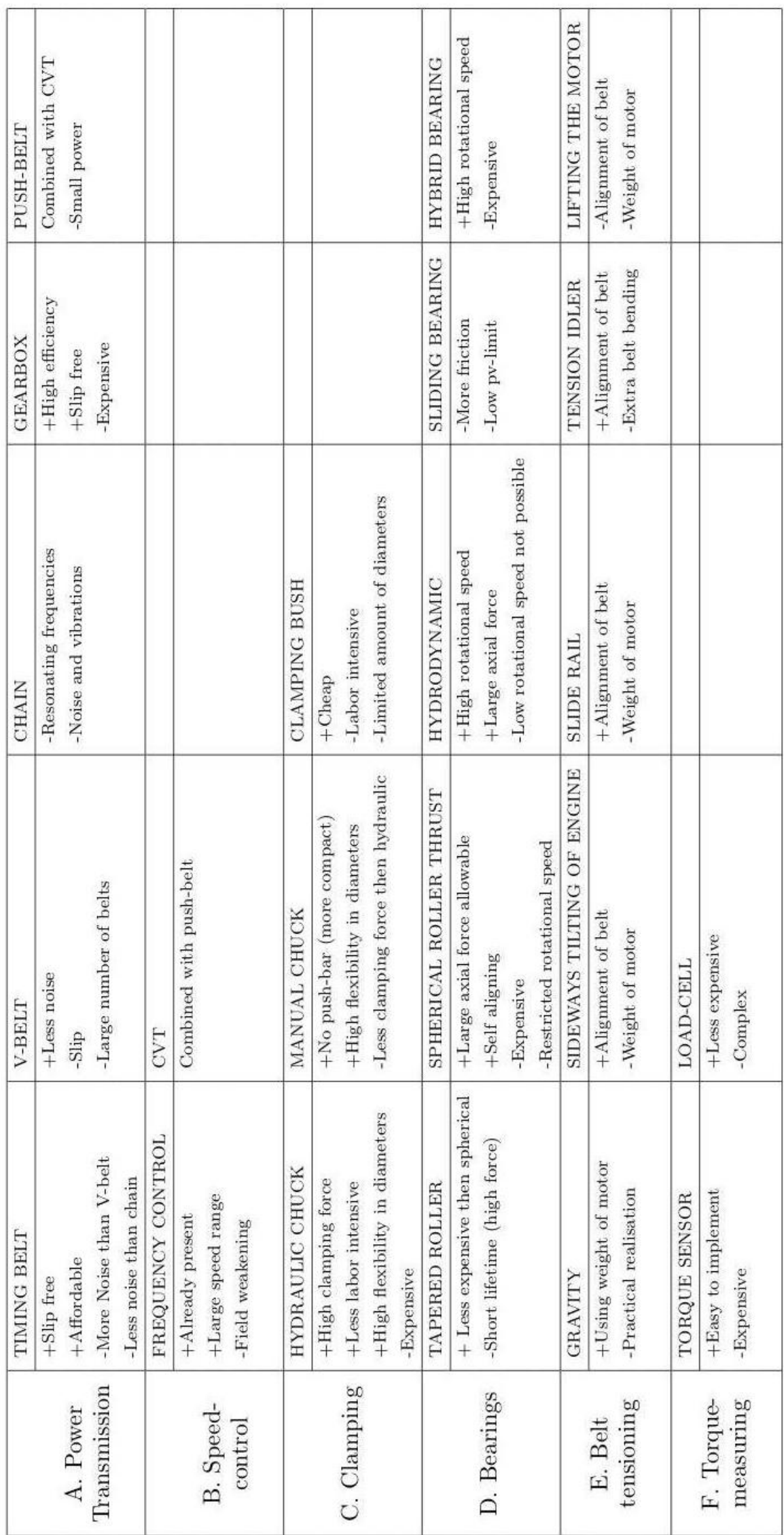

